\title{
Controlling Federal Outlays: Trends and Proposals
}

\author{
Keith M. Carlson
}

N his February 1985 budget message, President Reagan noted that

The past 4 years have also seen the beginning of a quiet but profound revolution in the conduct of our Federal Government. We have halted what seemed at the time an inexorable set of trends towatd greater and greater Government intrusiveness, more and nore regulation, higher and higher taxes, more and more spending, higher and higher inflation, and weaker and weaker defense. ${ }^{.}$

Yet, federal outlays as a proportion of GNP were still half a percentage point above what they were when the administration took office in 1981.

The purpose of this article is to summarize recent trends in federal outlays and assess the administration's future plans by placing them in a historical context. ${ }^{2}$ The focus of the discussion is on the behavior of federal outlays as a percent of GNP - a measure that was used initially by the administration to summarize the government's influence on the economy.

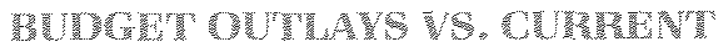 SHTR}

Interpreting budget trends requires some reference measure that can be used for comparison. The refer-

Keith $M$. Carison is an assistant vice president at the Federal Reserve Bank of St. Louis. Thomas A. Pollmann provided research assistance.

Otice of Management and Budget (1985a).

EEven though the administration's February 1985 proposals will not be realized, these proposals provide a base for debate by Congress whereby modifications wili be made. ence measure used in the February 1985 budget is the "current services budget." According to the budget document, "current services" estimates are defined as

. . . the estimated budget outlays and proposed budget authority that would be included in the budget for the following fiscal year if programs and activities of the United States Government were carried on during that year at the same level as the current year without a change in policy.

Current services estimates "provide a base against which budgetary alternatives may be assessed."

Table 1 summarizes both the administration's 1985 proposals and the current services estimates for $\mathbf{1 9 8 5}$ through $1990 .^{5} \mathrm{~A}$ comparison of the figures indicates that the administration plans to cut federal outlays by $\$ 507$ billion between 1986 and 1990 , with the largest cuts coming in the last three years. When converted to percentages, the cuts range from 5 percent in 1986 to 10.7 percent in 1990 .

The bottom half of table 1 shows the current services and proposed budget estimates as percentages of GNP. The proposed estimates represent sizable decreases in the proportion of federal government outlays to GNP compared with the current services estimates.

Whether such proposed reductions in the proportion of federal outlays relative to GNP will actually

${ }^{3}$ Office of Management and Budget (1985b), p. A-1.

'bid, p. A-2,

sFor alternative estimates of both the administration's program and current services, see Congressional Budget Office (1985). 
Table

Federal Outlays: Budget Estimates vs, Current Services, February 1985

\begin{tabular}{|c|c|c|c|c|c|c|}
\hline \multicolumn{7}{|c|}{ In Billions of Dollars } \\
\hline & 1985 & 1986 & 1987 & 1988 & 1989 & 1990 \\
\hline Current services & $\$ 9604$ & $\$ 10245$ & $\$ 1109.2$ & $\$ 12000$ & $\$ 12628$ & $\$ 13328$ \\
\hline Budget estimates & 9591 & 9737 & 1026.6 & 10948 & 11374 & 11900 \\
\hline \multirow[t]{2}{*}{ Diference } & $\$ 13$ & $\$ 50.8$ & $\$ 826$ & $\$ 1052$ & $\$ 1254$ & $\$ 1428$ \\
\hline & & & & $\$ 5068$ & & \\
\hline Percent dfference & $0, \%$ & $50 \%$ & $75 \%$ & $8,8 \%$ & $9.9 \%$ & $107 \%$ \\
\hline \multicolumn{7}{|c|}{ As a Percent of GNP } \\
\hline Cunentsenvices & $248 \%$ & $24,4 \%$ & $24,4 \%$ & $24,4 \%$ & $23.8 \%$ & $23,4 \%$ \\
\hline Budget estimates & 248 & 232 & 226 & 222 & 21.4 & 209 \\
\hline Diference & $0,0 \%$ & $12 \%$ & $13 \%$ & $22 \%$ & $24 \%$ & $25 \%$ \\
\hline
\end{tabular}

NOTE Al igures nnclude of budget oullays.

occur depends crucially on both political considerations and future economic conditions - neither of which can be forecast with much reliability. One way to assess the significance of the proposed reductions, however, is to compare them with some longer-term trends in federal outlays. In this manner, it is at least possible to see what such reductions would mean in a historical context.

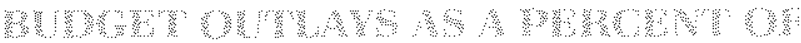

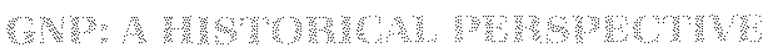

To examine properly federal outlays relative to GN from a historical perspective requires adjusting outlays and GNP separately for the direct influence of the business cycle. ' Since federal outlays generally rise relative to GNP during recessions, the inclusion of such percentages without adjustment could distort the interpretation of underlying trends.

\footnotetext{
See Carison (1983).

7 Federal outlays were adjusted for the cycle using correction factors implicit in the work by de Leeuw and Holloway (1983). This meant adjusting budget outlays in the same proportion as national income accounts federal expenditures are adjusted to derive cyclically adjusted expenditures. Following this procedure captures only the automatic response of federal outlays to the business cycie, meaning that countercyclical fiscal actions are still reflected in the figures Trend GNP is middle-expansion trend GNP as defined by de Leesw and Holloway. See also Holloway (1984).
}

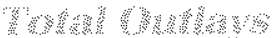

The historical record of cyclically adjusted feder: outlays as a percent of adjusted GNP is summarized $i$ chart 1. Even with cyclical adjustment, this measure $c$ government activity is still quite volatile, especially $o$ a year-to-year basis. Consequently, a trend line for th period 1956-81 has been plotted in the chart.

Extending the trend line from 1982 through 199 indicates that the administration has not been suc cessful in reducing total outlays as a percent of GNP i the 1981-84 period. Moreover, the proposed 1985 levt of outlays is well above the historical trend.

Chart 1 does show that the administration is pre posing a path of outlays after 1985 that differs dramat cally from both the 1956-81 trend and its first fou years in office. If the administration's proposals ar enacted, the size of government would be reduced $t$ that prevailing in the mid-1970s.

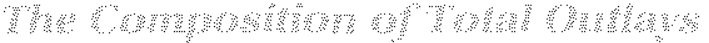

An examination of total budget outlays relative $t$ GNP masks the contrasting differences taking plac between defense and nondefense outlays. Chart summarizes these outlays relative to GNP. Nondefens outlays and GNP are adjusted for the business cycl defense outlays are not adjusted because they are no systematically related to the business cycle. The d fense portion of the chart shows the downward tren 


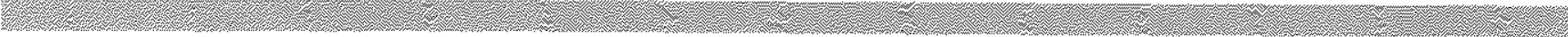

Chart I

\section{Total Budget Outlays as a Percent of GNP}

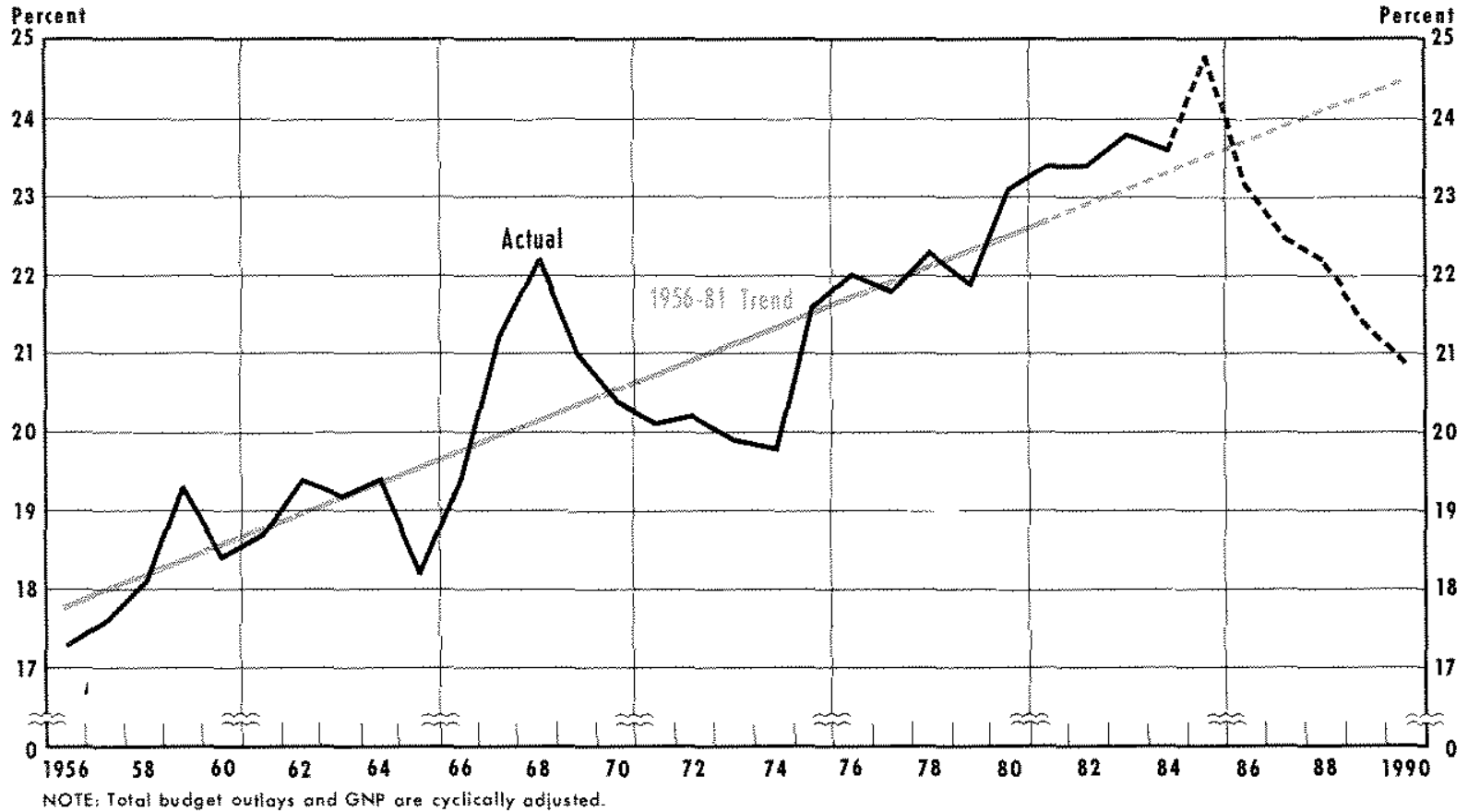

3.7.

of defense outlays relative to GNP from 1956 to 1981 . Since 1981, the trend has been reversed, with defense spending rising to 6.3 percent of GNP in 1984. The administration plans for future defense spending to continue to rise relative to GNP; the proposed budget calls for defense outlays to reach 7.5 percent of GNP by $1990 .^{8}$

The nondefense portion of the chart shows that the growth of cyclically adjusted nondefense outlays relative to trend GNP was extraordinarily rapid from 1956 to 1981 . Such spending rose from 6.9 percent of GNP in 1956 to 18 percent in 1981 . Since 1981, however, the ratio of nondefense outlays to GNP has been reduced relative to its $1956-81$ trend.

The administration plans for the reduction in nondefense outlays relative to GNP to continue; these reductions are quite dramatic relative to the $1956-81$ trend. The administration's proposals call for nonde-

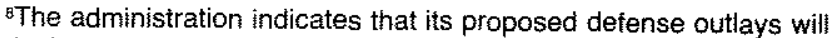
be less than the current services estimates (see the appendix to this article for 1990 estimates). The Congressional Budget Office disputes this contention, claiming that the administration's detense proposals are greater than current services estimates. See Con: gressional Budge: Office (1985), p. 22.
}

fense outlays to be reduced to 13.4 percent of GNP by 1990. If realized, the relative size of the nondefense budget would be reduced to levels prevailing in the early 1970 s.

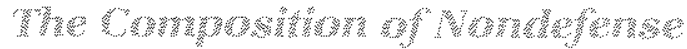

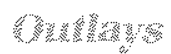

Chart 3 summarizes nondefense spending by major program category and emphasizes the method of carrying out government activities. The purpose of looking at these categories is to determine where the nondefense budget cuts will fall. ${ }^{9}$

The largest proportion of nondefense spending, given this set of categories, is payments for individuals. This category includes both direct (for example, Social Security benefits and indirect (via grants to state and local govemments, such as Medicaid and assistance payments) transfer payments by the federal government. According to the top tier of chart 3 , this spending grew rapidly from 1956 to 1981 ; its trend has apparently been reversed since 1983 . The administra-

${ }^{9}$ For further detail relative to current services estimates, see the appendix. 


\section{Composition of Total Budget Outlays Percent of GNP}
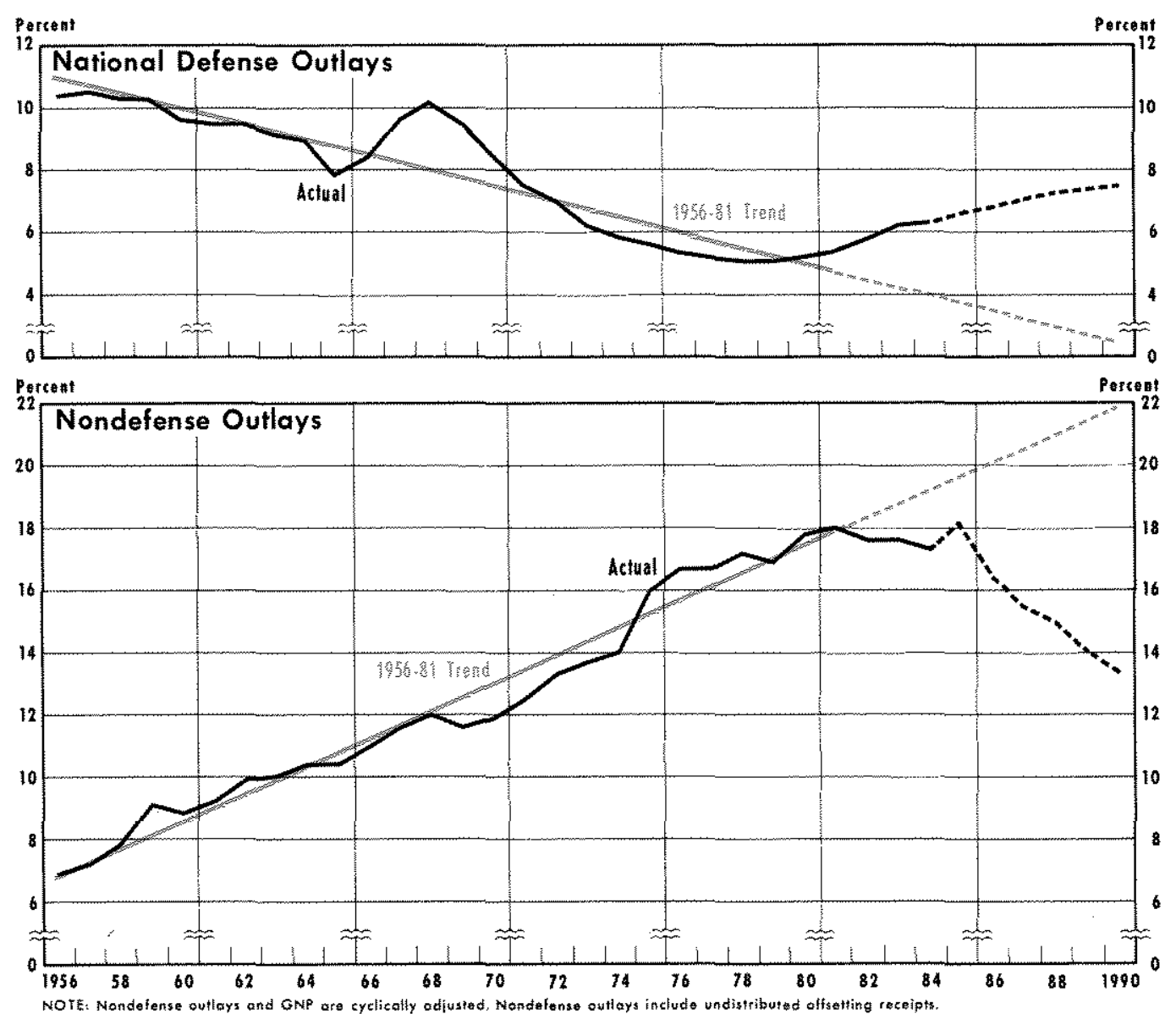

tion plans to continue to reduce such payments relative to GNP to 9.8 percent by 1990 , a dramatic departure from its growth over the 1956-81 period.

The category labeled "all other grants" includes all grants to state and local governments except transfer payments. Included in this category are grants for wastewater treatment plants, highway construction, community development, education, employment and training assistance, and general revenue sharing. The second tier of chart 3 indicates that this category of spending has been reduced well below the 1956-81 trend line in recent years. The extent of the cut is dramatic - from a peak of 2.6 percent of GNP in 1978 to 1.5 percent in 1984. Furthermore, this category is projected for further cuts in the future, to 0.9 percent of GNP in 1990 .
The net interest category has attracted considerab attention in recent years. Once a relatively insignil cant part of the budget, it has risen considerably to tr point where policymakers now view it with maji concern. ${ }^{10}$ The third tier of chart 3 shows that, aft, rising from 1.3 percent of GNP in 1956 to 1.6 percent $i$ 1976 , net interest rose steadily to 3.1 percent of GNP 1 1984. Projections of net interest depend on a numb of factors, the most important of which is the futu course of deficits and the projected level of intere

10This is because of the cumulative effect of net interest. Higher $n$ interest adds to the current deficit, which carries over to future yea in the form of a larger debt that must be tinanced. See Carts (1984). 


\section{Composition of Nondefense Outlays Percent of GNP}
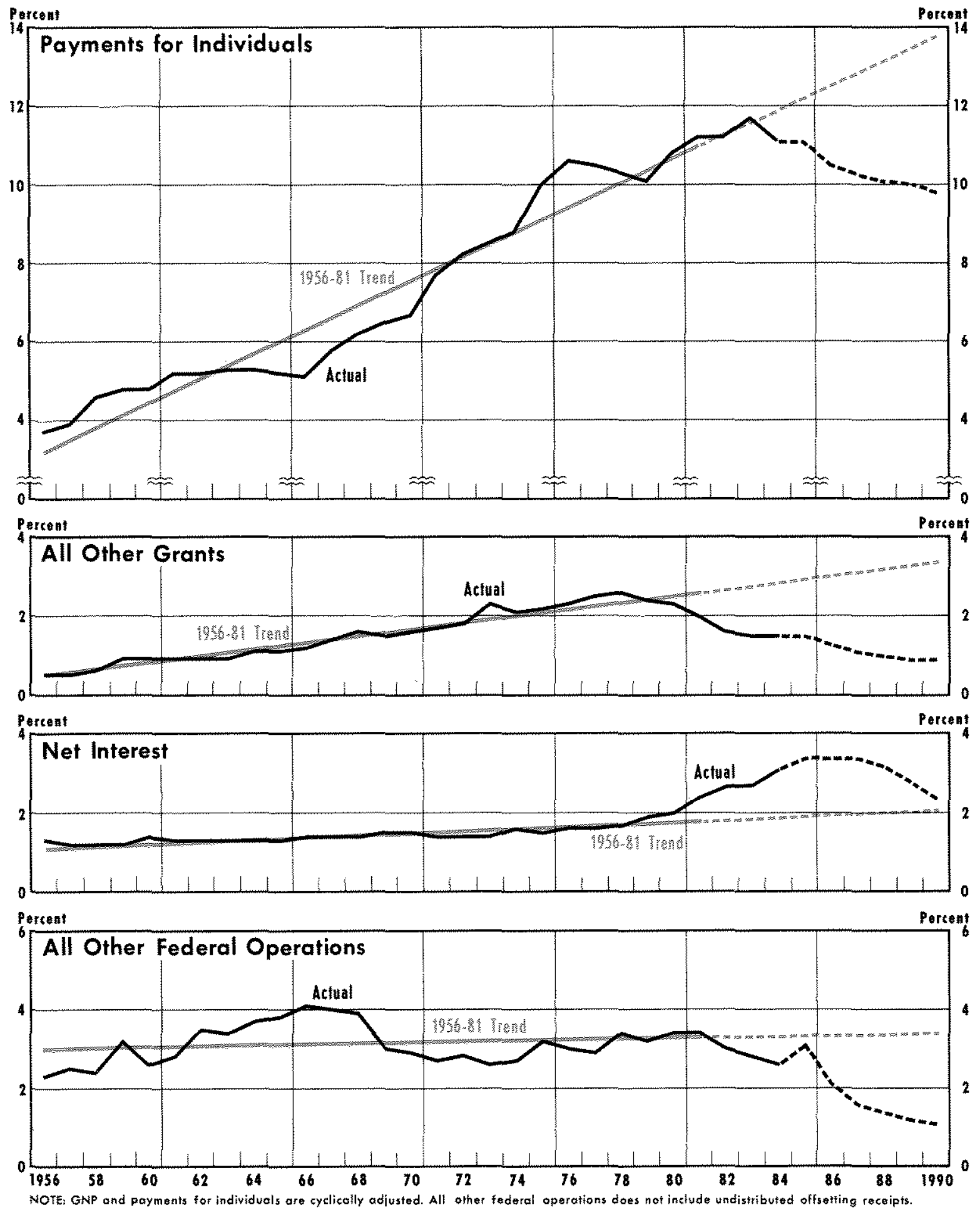
rates. Given the administration's overall plan for reducing the size of the deficit and a projected decline in interest rates, net interest outlays as a percent of GNP is projected to continue rising through 1985 , level off for two years, then drop sharply to 1990; however, it will still remain above the $1956 m 81$ trend as extrapolated to 1990.

The "all other federal operations" category includes outlays for foreign aid, general science research and space technology, energy programs, farm price supports, housing credit activities and day-to-day operations of the government. Relative to GNP, as shown in the bottom tier of chart 3 , this category of nondefense outlays displayed a slight upward trend during the 1956-81 period; it has declined in recent years. The jump in the estimate for fiscal yea: 1985 reflects primarily the surge in outlays related to the PIK farm program. The administration plans to continue to cut such outlays as a percent of GNP through 1990. Such proposed cuts are centered on farm price support programs, foreign aid and loan activities of the government.

\section{3.}

The federal government in its February 1985 budget announced cuts of about $\$ 507$ billion relative to curm rent services estimates for the 1986-90 period. These proposed cuts were compared with recent trends in federal outlays relative to GNP since 1956; the results of these comparisons are summarized in table 2. The historical record indicates that, while attempts to cut the proportion of total federal outlays to GNP have been unsuccessful thus far, the administration's current proposals, if achieved, would reduce outlays relative to GNP. The historical comparisons show the present administration has altered the mix of total outlays between defense and nondefense quite dramatically, and a continuation of this reversal is proposed for the future.

Payments for individuals are scheduled to be cut moderately relative to GNP for each year after 1985. Net interest as a percent of GNP, which is currently climbing well above past trends, is projected to continue rising through 1985, level off, then move back toward
Table 2

\section{Summary of Trends}

\begin{tabular}{|c|c|c|}
\hline \multirow[b]{2}{*}{ Percentol $\mathrm{oNO}$} & \multicolumn{2}{|c|}{ Relation } \\
\hline & $1982-64$ & 198590 \\
\hline 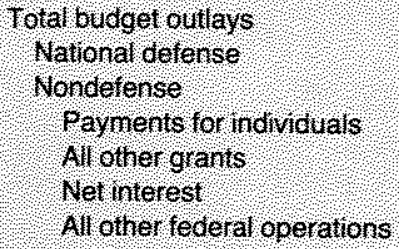 & $\begin{array}{l}\text { Above } \\
\text { Above } \\
\text { Below } \\
\text { Below } \\
\text { Below } \\
\text { Beove }\end{array}$ & $\begin{array}{l}\text { Bolow } \\
\text { Boflow } \\
\text { Below } \\
\text { Below } \\
\text { Boove } \\
\text { selow }\end{array}$ \\
\hline
\end{tabular}

trend after 1987. Budget cuts, as measured by outlay. relative to GNP, are concentrated in "all other grants tt state and local governments" and in "all other federa operations." The government's program is ambitious in order to reduce total budget outlays to 20.9 percen of GNP by 1990, while at the same time increasing defense outlays to 7.5 percent of GNP, nondefens, outlays will have to be reduced to 13.4 percent of GN] from the current level of approximately 18 percent.

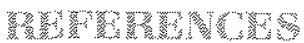

Carison, Keith M. "The Critical Role of Economic Assumptions in the Evaluation of Federal Budget Programs," this Review (Octobe 1983), pp. $5-14$.

. "Money Growth and the Size of the Federal Debt," thi Review (Novernber 1984), pp. 5-16.

Congressional Budget Office. An Analysis of the President's Bud getary Proposals for Fiscal Year 1986 (February 1985).

de Leeuw, Frank, and Thomas M. Holloway. "Cyclical Adjustmen of the Federal Budget and Federal Debt." Survey of Current Busi ness (December 1983), pp. 25-40.

Holloway, Thomas M. Cycical Adjustment of the Federal Budge and Federal Debt: Detailed Methodology and Estimates, Bureau o Economic Analysis Staff Paper 40 (U.S. Department of Com merce, June 1984).

Office of Management and Budget. Budget of the United States Government: Fiscal Year 1986 (February 1985a), p. M4

Special Analysis: Budget of the United States Govern ment: Fiscal Year 1986 (February 1985b).

\section{APPUNDN: Composilion of Federal Outhys}

Federal outlays can be classified in terms of two analytical structures: budget function and major pro- gram category. The functional classification presents outlays according to the purposes that federal pro- 
(a)

\section{Table A1}

1990 Federal Outlays: Current Services vs. Administration Proposals (amounts in billions of dollars)

\begin{tabular}{|c|c|c|c|c|}
\hline Category & $\begin{array}{l}\text { Current: } \\
\text { services }\end{array}$ & $\begin{array}{l}\text { Administration } \\
\text { proposal }\end{array}$ & Diference & $\begin{array}{l}\text { Percent } \\
\text { difference }\end{array}$ \\
\hline National defense & $\$ 447$ & $\$ 428.6$ & $\$ 131$ & $30 \%$ \\
\hline Benetit payments for ndividuals & 5906 & 5550 & -35.6 & -60 \\
\hline Health & 48.9 & 408 & 88 & -166 \\
\hline Socral Secunty and Medicare & 3692 & 3554 & 130 & ?37 \\
\hline Income secunty & 1408 & 1306 & 102 & 72 \\
\hline Veleranpaynents & 311 & 28.2 & & 6809 \\
\hline Other grants to state and local governments? & 612 & 439 & 173 & 28.3 \\
\hline National resources and onvironment ${ }^{2}$ & 35 & 27 & \$18 & 229 \\
\hline Transportation' & 222 & 168 & 55.4 & 243 \\
\hline Community and regional developmen'? & 57 & 38 & 1.9 & -33.3 \\
\hline $\begin{array}{l}\text { Education training enployment and } \\
\text { social serices? }\end{array}$ & 227 & 187 & $\div 40$ & 176 \\
\hline General purpose fiscal assistanee & 71 & 19 & 452 & 7732 \\
\hline Net interest & 1642 & 1377 & 26 & \\
\hline other federal operations' & 1173 & 69.9 & -474 & -404 \\
\hline Intemational aftairs & 195 & 14.5 & ४ 50 & -256 \\
\hline General service space and technology & 11.0 & 111 & ?01 & 0,9 \\
\hline Energy & 61 & 23 & +3.8 & +623 \\
\hline Natural resources and environment? & 9.3 & 73 & ?2, & 42,5 \\
\hline Agriculure & 201 & 3.8 & 163 & -1974 \\
\hline Conmerce and housing credt & 3,8 & 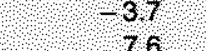 & 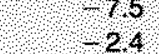 & $?_{240}$ \\
\hline Transportation? & 100 & 18 & 108 & -320 \\
\hline $\begin{array}{l}\text { Community and regional development? } \\
\text { Education, traning, enployment and }\end{array}$ & $<0$ & & & \\
\hline social services $\left.^{2}\right)_{4}$ & 116 & 95 & 22 & 4181 \\
\hline Adminstration of Justice & 74 & 69 & 05 & 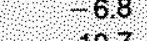 \\
\hline General government & 61 & 49 & 112 & 197 \\
\hline Allowances & 99 & 40 & $-5,9$ & 39.6 \\
\hline Undistrbuted oftseting receipts & -42. & 450 & 29 & \\
\hline
\end{tabular}

Anounis shown are the sums tor the tunctons Isted under them, and difer slightly trom the major progran categony amounts shown in the budget

The budgel gives current services estimates for the total. Estimates by major program categony were estimated by the author

grams are intended to serve. These functions are grouped into 18 broad areas, including, for example, national defense, international affairs, energy pro grams, agriculture, transportation, health and general government programs. Three additional categories net interest, allowances and undistributed offsetting receipts - do not address specific functions, but are included to cover the entire budget.

Classification of federal outlays by major program category focuses on the method of carrying out an activity. The major program categories are national defense, benefit payments to individuals, grants to state and local governments lother than for benefit payments), net interest, other federal operations and undistributed offsetting receipts. National defense, net interest, and undistributed offsetting receipts correspond to the functional categories of the same name, but, the remaining major program categories do not correspond to a simple summing of functional categories. Nonetheless, approximations can be made. The accompanying table groups 1990 outlays by function to show the approximate composition of some of the major program categories. 